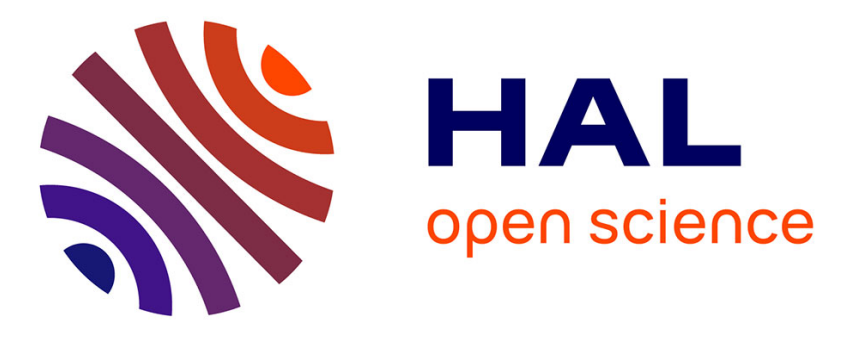

\title{
Impact of Preoperative Iron Deficiency on Blood Transfusion in Elective Cardiac Surgery
}

\author{
Marine Hubert, Baptiste Gaudriot, Sebastien Biedermann, Hervé Gouezec, \\ Emmanuelle Sylvestre, Guillaume Bouzillé, Jean-Philippe Verhoye, Erwan \\ Flecher, Claude Ecoffey
}

\section{To cite this version:}

Marine Hubert, Baptiste Gaudriot, Sebastien Biedermann, Hervé Gouezec, Emmanuelle Sylvestre, et al.. Impact of Preoperative Iron Deficiency on Blood Transfusion in Elective Cardiac Surgery. Journal of Cardiothoracic and Vascular Anesthesia, 2019, 33 (8), pp.2141-2150. 10.1053/j.jvca.2019.02.006 . hal-02086792

\section{HAL Id: hal-02086792 \\ https://hal-univ-rennes1.archives-ouvertes.fr/hal-02086792}

Submitted on 23 May 2019

HAL is a multi-disciplinary open access archive for the deposit and dissemination of scientific research documents, whether they are published or not. The documents may come from teaching and research institutions in France or abroad, or from public or private research centers.
L'archive ouverte pluridisciplinaire HAL, est destinée au dépôt et à la diffusion de documents scientifiques de niveau recherche, publiés ou non, émanant des établissements d'enseignement et de recherche français ou étrangers, des laboratoires publics ou privés. 
Impact of preoperative iron deficiency on blood transfusion in elective cardiac surgery

Marine Hubert ${ }^{1}$, Baptiste Gaudriot ${ }^{1}$, Sebastien Biedermann ${ }^{1}$, Hervé Gouezec ${ }^{2}$, Emmanuelle Sylvestre ${ }^{3}$ 4,5,6, Guillaume Bouzille ${ }^{3,4,5,6}$, Jean-Philippe Verhoye ${ }^{7,8}$, Erwan Flecher, ${ }^{7,8}$, and Claude Ecoffey ${ }^{1,4,7}$.

1. CHU Rennes, Anesthésie-Réanimation CTCV, F-35033 Rennes, France

2. CHU Rennes, Hémovigilance et Sécurité Transfusionnelle, F-35033 Rennes, France

3. INSERM, U1099, F-35000 Rennes, France

4. Inserm CIC-1414, F-35000 Rennes, France

5. CHU Rennes, Centre de Données Cliniques, F-35033 Rennes, France

6. Université de Rennes 1, LTSI, F-35000 Rennes, France

7. Université de Rennes 1, Faculté de Médecine, F-35000 Rennes, France

8. CHU Rennes, Chirurgie Thoracique et Cardiovasculaire, F-35033 Rennes, France

\section{Corresponding author:}

Baptiste Gaudriot, Service d'Anesthésie-Réanimation CTCV, Centre Cardio-Pneumologique, Hôpital Pontchaillou, 2 rue Henri Le Guilloux, 35033 Rennes Cedex 9, France.

(E-mail: baptiste.gaudriot@chu-rennes.fr)

\section{Funding:}

This research did not receive any specific grant from funding agencies in the public, commercial, or not-for-profit sectors.

\section{Declarations of interest:}

None.

Impact of preoperative iron deficiency on blood transfusion in elective cardiac surgery

\section{Abstract (229 words)}


Objective: To evaluate the incidence and consequences of preoperative iron deficiency in elective cardiac surgery.

Design: A prospective observational study.

Setting: The cardiac surgery unit of a university hospital, from November 2016 to February 2017.

Participants: All patients presenting for elective cardiac surgery during the study period, with the exclusion of non-cardiac thoracic surgeries, surgeries of the descending aorta, endovascular procedures, and patients affected by an iron-metabolism disease.

Intervention: Transferrin saturation and serum ferritin levels were systematically assessed before surgery and the care of patients maintained as usual.

Measurements and Main Results: Routine analyses, clinical data, and the number of blood transfusions were recorded during the hospital stay. Among the 272 patients included, $31 \%$ had preoperative iron deficiency, and $13 \%$ were anemic. Patients with iron deficiency had significantly lower hemoglobin levels throughout the hospital stay and received blood transfusions more frequently during surgical procedures ( $31 \%$ vs. $19 \%, p=0.0361)$. Detailed analysis showed that patients with iron deficiency received more red blood cell units. There were no differences in postoperative bleeding, morbidity, or mortality.

Conclusions: Iron deficiency appears to be related to lower hemoglobin levels and more frequent transfusion in elective cardiac surgery. Assessing iron status preoperatively and correcting any iron deficiencies should be one of the numerous actions involved in patient blood management for such surgeries, with the aim of reducing morbidity due to both anemia and transfusion.

\section{Key words:}

- cardiac surgery, iron deficiency, anemia, blood transfusion, cardiopulmonary bypass 


\section{Impact of preoperative iron deficiency on blood transfusion in elective cardiac surgery}

\section{Introduction}

Blood transfusion is a major concern in cardiac surgery. Indeed, the risk of hemorrhage is an important issue during both intraoperative (sternotomy, cardiopulmonary bypass (CPB) and the accompanying required anticoagulation, and induced thrombopathy) and postoperative periods (coagulation and fibrinolysis disorders, postoperative bleeding, mediastinal drain clotting, pericardial tamponade, etc.). It often concerns elderly and vulnerable patients, who have a low tolerance to anemia. Although guidelines have been published to help clinicians with blood transfusion (1-3), especially for thoracic surgery (4-5), the proportion of patients that receives a perioperative blood transfusion still depends on the type of surgery, the center, and the designated hemoglobin thresholds (6-14). It can vary from 8 to $93 \%(15)$. The statistics of morbidity and mortality related to blood transfusion are well established in cardiac surgery (8-10; 16-19). For example, an English cohort showed that red blood cell (RBC) transfusion was associated with an increased incidence of infections (septicemia and pulmonary tract infections), ischemic complications (acute coronary syndrome and stroke), and acute renal failure, resulting in an increase in hospital length of stay and costs, and increased short-and medium-term mortality (20).

Anemia, defined by the World Health Organization (WHO) as a hemoglobin level $<13 \mathrm{~g} / \mathrm{dL}$ for men and $<12 \mathrm{~g} / \mathrm{dL}$ for women, occurs in 10 to $11 \%$ of patients older than 65 years of age in the general population (21), and $26 \%$ of patients presenting for cardiac surgery (22). Anemia is an independent factor of morbidity, mortality, and perioperative blood transfusion $(23,24)$. Among patients presenting for coronary bypass surgery, a hematocrit level $<33 \%$ is associated with significantly higher rates of acute renal failure, stroke, mediastinitis, and longer duration of mechanical ventilation (25). 
Iron deficiency (ID), defined by a serum ferritin level $<100 \mathrm{ng} / \mathrm{mL}$, or $<300 \mathrm{ng} / \mathrm{mL}$ in association with transferrin saturation $<20 \%(26)$, is the most common cause of anemia (27). Half of patients with cardiac heart failure have ID (28), as well as $37 \%$ of patients presenting for cardiac surgery. It is an independent factor of blood transfusion and postoperative fatigue (29). ID can be easily treated by iron supplementation. Indeed, ferric carboxymaltose improves the exercise capacity, cardiac function, and quality of life of patients with chronic heart failure (30).

Preventing complications and morbidity due to anemia and blood transfusion is a key element in cardiac surgery and requires a patient blood-management (PBM) strategy (31), including the correction of ID as a major component. We aimed to evaluate the incidence of preoperative ID and ID anemia (IDA) in our population of patients presenting for elective cardiac surgery, as well as secondary outcomes to evaluate its association with blood transfusion (all transfusions and that of RBCs, plasma, and platelets), hemoglobin levels, and mortality during the hospital stay.

\section{Patients \& Methods}

\section{Patient population}

We determined the size of the study population based on retrospective observations in our surgery population and published data. Considering that: a) approximately $20 \%$ of the patients in our population appeared to suffer from anemia, b) ID affects $37 \%$ of cardiac surgery patients (29), and c) ID is the first cause of anemia, we hypothesized that anemia would be found in $15 \%$ of patients without ID and $25-30 \%$ of ID patients. With an $\alpha$ risk of $5 \%$ and $\beta$ at $20 \%$, the number of patients to be included was 242 or more. We expected to include 20 patients per week and planned the inclusions over 3.5 months.

We conducted this prospective observational study from November 14, 2016 to February 26, 2017 in our university hospital. Every patient presenting for elective cardiac surgery, with or without 
$\mathrm{CPB}$, was included prospectively. Exclusion criteria were: patients younger than 18 years of age or legally protected adults, endovascular procedures (trans-aortic valve replacement (TAVR) and all percutaneous techniques), non-cardiac thoracic surgeries, surgeries on the descending aorta, and patients affected by an iron metabolism disease or for whom preoperative iron status could not be determined.

\section{Study procedures and data collection}

We assessed cardiac function (symptoms, echocardiography, and coronarography), cardiovascular risk factors, respiratory function (symptoms and lung-function test), and vascular diseases (symptoms and supra-aortic vessel echography), according to our routine preoperative evaluation. A blood sample was systematically collected several days before surgery and the blood count, platelet count, and coagulation factors were determined, and an ionogram, including the serum creatinine level and glomerular filtration rate (estimated by the CKD - EPI formula), performed. Serum ferritin, transferrin, and iron levels were systematically determined during the study. Transferrin saturation (Tsat) was calculated as follows: Tsat (\%) = serum iron $(\mu \mathrm{mol} / \mathrm{L}) /($ serum transferrin $(g / L) \times 25)$.

A central venous catheter in the cava superior territory (or a Swann-Ganz catheter for the most vulnerable patients) and a radial arterial catheter were placed in every patient. The management of CPB (cannulation, cardioplegia, tubes, and cardiotomy reservoir) varied, depending on the choices of the surgeon and perfusionist. The modality of general anesthesia was decided by the anesthesiologist.

Blood loss and transfusion during surgery were prevented, according to our institutional protocol, as follows: a) tranexamic acid was injected at a dose of $2.5 \mathrm{~g}$ during the induction of general anesthesia and at the end of $\mathrm{CPB}$ as an antifibrinolytic agent; b) intraoperative cell salvage was systematically performed, if not contraindicated (Cell-Saver ${ }^{\circledR}$, Haemonetics); and c) anticoagulation required by CPB was achieved using unfractionated heparin and monitored via activated clotting 
time (ACT), with a target of 450 seconds during CPB. Calculations were performed by Heparin Management System-Plus (HMS-Plus ${ }^{\circledR}$, Medtronic Inc.) during surgery, based on an algorithm that includes the prime volume and patient morphology. The appropriate dose of protamine required after decannulation was calculated using the same device. The decision to perform a blood transfusion was made by the anesthesiologist if the hematocrit decreased to $22 \%$ during CPB, for cold crystalloid cardioplegia, or $22-25 \%$, for warm blood cardioplegia, and was based on the French recommendations on hemoglobin levels for the following postoperative period (2).

During the postoperative period, every patient was admitted to the intensive care unit (ICU) for at least 48 hours with daily clinical, biological, and echocardiographic evaluations. Data were collected prospectively through a data collection form, completed by the anesthesiologists in charge of the patient. After the ICU period, patients were transferred to the surgery unit and data were collected through the patient computerized folder.

The study protocol was approved by the ethics committee of the university hospital (notice $n^{\circ} 16.121$ of October 7,2016$)$. Patients received oral and written information before their inclusion, and written consent was required.

\section{Statistical analysis}

We compared two groups of patients defined by their ID status, as previously described. The descriptive analysis was performed using $\mathrm{R}^{\circledR}$ software, version 3.3.2. Quantitative variables are presented as the mean +/- standard deviation (SD), with the number of patients (n). Groups were compared using the parametric $t$ test of Student or the non-parametric test of Wilcoxon, depending on the number of patients analyzed. Categorical variables are presented as the number of patients by percentage: $\mathrm{n}(\%)$. We compared the groups using the $\chi^{2}$ test or Fisher's exact test, depending on the number of patients. A difference was considered significant for $p<0.05$. 


\section{Results}

The flowchart of the study is shown in Figure 1. The general characteristics and preoperative cardiological evaluation of the population are shown in Tables 1 and 2. In our population $(n=272)$, $31 \%$ of patients had preoperative ID. There were no differences between the two groups, apart from the number of women and smaller size of the individuals, who were more likely to be in the ID group. Most of the surgical procedures were cardiac valve replacements and coronary bypasses Table 3). Among valve replacements, most concerned the aortic valve (35\% of surgeries); only $7 \%$ were mitral valve surgeries (replacement or plasty) and only one tricuspid surgery was performed during the study period. We practiced significantly more coronary bypasses and fewer combined surgeries in the group without ID.

\section{Iron deficiency lowers hemoglobin levels}

Thirteen percent of the patients had anemia before surgery. Hemoglobin levels were significantly lower among patients with ID throughout their hospital stay (Figure 2) and the proportion of anemic patients among them was greater ( $19 \%$ vs. $10 \%, p=0.066)$ (Table 4). The nonID group contains two kinds of patients: those with ferritin levels $>300 \mathrm{ng} / \mathrm{mL}$ and those with Tsat $>$ $20 \%$. Some of them thus present with a ferritin level between 100 and $300 \mathrm{ng} / \mathrm{mL}$ but a Tsat $>20 \%$, as well as others with a Tsat $<20 \%$ but a ferritin level $>300 \mathrm{ng} / \mathrm{mL}$.

\section{Iron deficiency increases the risk of blood transfusion}

Patients with preoperative ID were more likely to receive a blood transfusion during the intraoperative period, including that of RBCs, fresh frozen plasma, platelets and fibrinogen (Figure 3). Furthermore, the number of RBC transfusions was significantly higher during the intraoperative period for the group with ID, as well as during the complete hospital stay (table 5). 
A more detailed analysis of RBC transfusion showed that patients without ID generally received one or two units of RBCs, whereas patients with ID were more likely to receive two or more units (Table 6). However, only $29 \%$ of patients transfused with RBCs received three units or more (7\% of the study population), and there was no difference between the two groups. This statistical analysis only covered patients who were still alive at the end of hospital stay $(n=265)$.

An analysis of postoperative complications showed no difference between patients with or without ID (Table 7).

\section{Discussion}

The prevalence of ID in our study was 31\%, similar to previously published data (29). ID is the most frequent cause of anemia worldwide (27) and is responsible for microcytic, hypochromic, and regenerative anemia. ID is defined by serum ferritin levels $<100 \mathrm{ng} / \mathrm{mL}$ or $<300 \mathrm{ng} / \mathrm{mL}$, when associated with transferrin saturation $<20 \%(26)$, defining two different types of ID: absolute and functional. Iron levels in the blood are regulated by the hormone hepcidin (32). Hepcidin inhibits intestinal iron absorption and regulates iron distribution in the tissues by inducing the degradation of its receptor, the cellular iron exporter ferroportin (33). The synthesis of hepcidin increases with inflammation (cancer, inflammatory bowel disease, chronic cardiac dysfunction, etc.), resulting in a decrease of circulating iron levels and causing functional iron deficiency, whereas serum ferritin levels often increase. Surgery and CPB also cause inflammation, resulting in the production of mediators that decrease erythropoiesis, causing anemia. Numerous mechanisms are involved: an increase in hepcidin synthesis, increased macrophage activity and phagocytosis of RBCs, inhibition of erythropoietin synthesis, and decreased sensitivity of erythroblasts to erythropoietin (32). These phenomena all lead to decreased hemoglobin levels, preoperative anemia, surgical blood loss, and hemodilution. 
There was a higher prevalence of preoperative anemia among patients with ID, although it was not significant. Hemoglobin levels and the hematocrit during CPB were both significantly lower for patients with ID throughout their hospital stay. Indeed, their hemoglobin levels before surgery were, on average, $0.7 \mathrm{~g} / \mathrm{dL}$ lower than those of the other group and this gap remained the same until hospital discharge. We suspect that this gap likely explains the higher frequency of blood transfusion for ID patients, in particular during the intraoperative period and CPB, which results in hemodilution, as the groups were comparable in terms of known hemorrhagic risk factors (length and complexity of the surgery, circulatory arrest, and preoperative antithrombotic treatment) and postoperative hemorrhagic complications.

The frequency of intraoperative transfusions was low in our cohort (22\%) relative to that in the literature. It was however significantly higher for patients with ID than those without (31\% vs. $19 \%, p=0.04)$, but this difference disappeared during the postoperative period, for which the frequency was still relatively low ( $14 \%$ in the ICU and $4 \%$ in the surgical department). ID patients also more frequency underwent RBC transfusion during surgery ( $23 \%$ vs. $12 \%, p=0.03)$ and this trend continued during the postoperative period, but it was not significant $(30 \%$ vs. $22 \%, p=0.20)$. As previously described $(22,29)$, anemia was an independent risk factor of blood transfusion in our cohort, regardless of iron status. The number of units transfused was remarkably low and $7 \%$ of patients of both groups received only one unit of RBCs, whereas patients with ID were more likely to receive two units or more ( $23 \%$ vs. $15 \%)$.

The decision to perform a transfusion was left to the anesthesiologist in charge of the patient. The thresholds for RBC transfusion in our department are restrictive and are a component of a PBM strategy. In the current French guidelines, the transfusion threshold in the context of acute anemia for surgery and critical care is below $7 \mathrm{~g} / \mathrm{dL}$ for patients with no particular history and $10 \mathrm{~g} / \mathrm{dL}$ for vulnerable patients who cannot tolerate lower levels of hemoglobin and those with acute coronary insufficiency or cardiac failure. A threshold of $8-9 \mathrm{~g} / \mathrm{dL}$ during the perioperative period is recommended for patients with a cardiovascular history (2). Since 2016, the American Association of 
Blood Banks (AABB) has recommended a restrictive blood transfusion strategy, with a threshold of 7 $\mathrm{g} / \mathrm{dL}$, even in the ICU, except in the context of acute coronary syndrome, severe thrombocytopenia, or high hemorrhage risk situations (3). In the context of orthopedic and cardiac surgery, the minimal threshold rises to $8 \mathrm{~g} / \mathrm{dL}$ or a hematocrit of $25 \%$. The use of antifibrinolytic agents, such as tranexamic acid, is also recommended to prevent $\mathrm{RBC}$ transfusions for cardiac surgeries with $\mathrm{CPB}$, orthopedic surgeries associated with a high risk of hemorrhage, and hepatic surgeries (34). RBC transfusion should be performed one unit at a time, if possible. Our practices are in line with national and international guidelines.

Platelet transfusion during surgery is mainly based on preoperative thrombopenia (platelets $<150 \mathrm{G} / \mathrm{L}$ ) and an extended period of CPB (> 120 - 140 minutes). In this situation, as well as during surgery of the ascending aorta with circulatory arrest, platelet transfusion is often associated with the use of fibrinogen. The transfusion of fresh frozen plasma (FFP) is generally based on abnormalities observed in preoperative coagulation tests /aside from those due to antithrombotic therapy) and an extended period of CPB. The transfusion of FFP, platelets, or fibrinogen can also be based on surgical observations (intraoperative hemorrhage, seepage, or hemostasis difficulties) or abnormalities observed in new coagulation tests, such as thromboelastometry. Our results show that non-deficient patients received more FFP and fibrinogen in the ICU than other patients. This is likely a consequence of the low incidence of transfusion and the low number of transfused patients, and not clinical factors.

Morbidity and mortality induced by blood transfusion have been widely documented (8-10; 16-19). Koch et al. suggested that RBC transfusion is associated with a higher risk of mortality, acute kidney injury (AKI), prolonged mechanical ventilation, cardiac complications, and postoperative neurological complications (35). In the non-inferiority study TRACS (Transfusion Requirements After Cardiac Surgery), published in 2010, a restrictive strategy (a hematocrit $\geq 24 \%$ ) led to less transfusion than a liberal strategy (hematocrit threshold of $30 \%$ ), without any difference in mortality at day 30. Every RBC unit transfused increased the risk of morbidity (acute heart failure, acute respiratory 
distress syndrome, acute kidney failure requiring temporary renal dialysis) and mortality at day 30 with a hazard-ratio of 1.2, regardless of the chosen strategy (36). For cardiac surgery, the risk of AKI increased by $60 \%$ in the context of moderate preoperative anemia ( 10 to $12 \mathrm{~g} / \mathrm{dL}$ ) and by $8 \%$ for each transfused RBC unit (37). The incidence of postoperative acute kidney failure in our study was low (10\%) and does not appear to be related to the preoperative iron status. There was also no significant difference between the two groups of patients concerning the prognostic score for the first 24 hours in the ICU (IGS2 score), the incidence of postoperative infections, or mortality during the first month. However, these were only secondary objectives, and the incidence of these complications was relatively low in elective surgery; our study would have needed to include more patients to show a possible difference.

A PBM strategy is recommended to favor the restricted use of blood transfusion and needs to be applied at every step of patient care $(38,39)$. In cardiac surgery, this strategy includes unit-byunit blood transfusion, volume reduction of the circuit used for $\mathrm{CPB}$, intraoperative retransfusion, and administration of antifibrinolytic drugs. Such a strategy results in reduced blood transfusion, postoperative AKI, and length and cost of hospital stay $(31,40)$. Since 2016 , experts from the French Society of Anesthesiology and Critical Care have recommended determining blood counts to detect ID three to four weeks prior to surgery for elective cardiac and non-cardiac procedures with a high risk of hemorrhage. In cases of ID, intravenous administration of iron should be performed at least 21 days before surgery (41). The correction of preoperative ID could increase hemoglobin levels before surgery, thus avoiding the transfusion of one or two RBC units, particularly in the operating room. This needs to be confirmed by further studies in the context of cardiac surgery.

In conclusion, ID is common in elective cardiac surgery patients and associated with anemia and increased RBC transfusion. Although transfusions appear to have decreased during the last few years, due to restrictive strategies and improvements in the surgical and anesthetic management of patients, detecting and correcting preoperative ID prior to surgery, as part of a PBM strategy, could help to increase hemoglobin levels and prevent both anemia and blood transfusions. We therefore 
suggest establishing a clinical pathway from decision to operate to hospital discharge that is centered on anemia and transfusion, as presented in Figure 4.

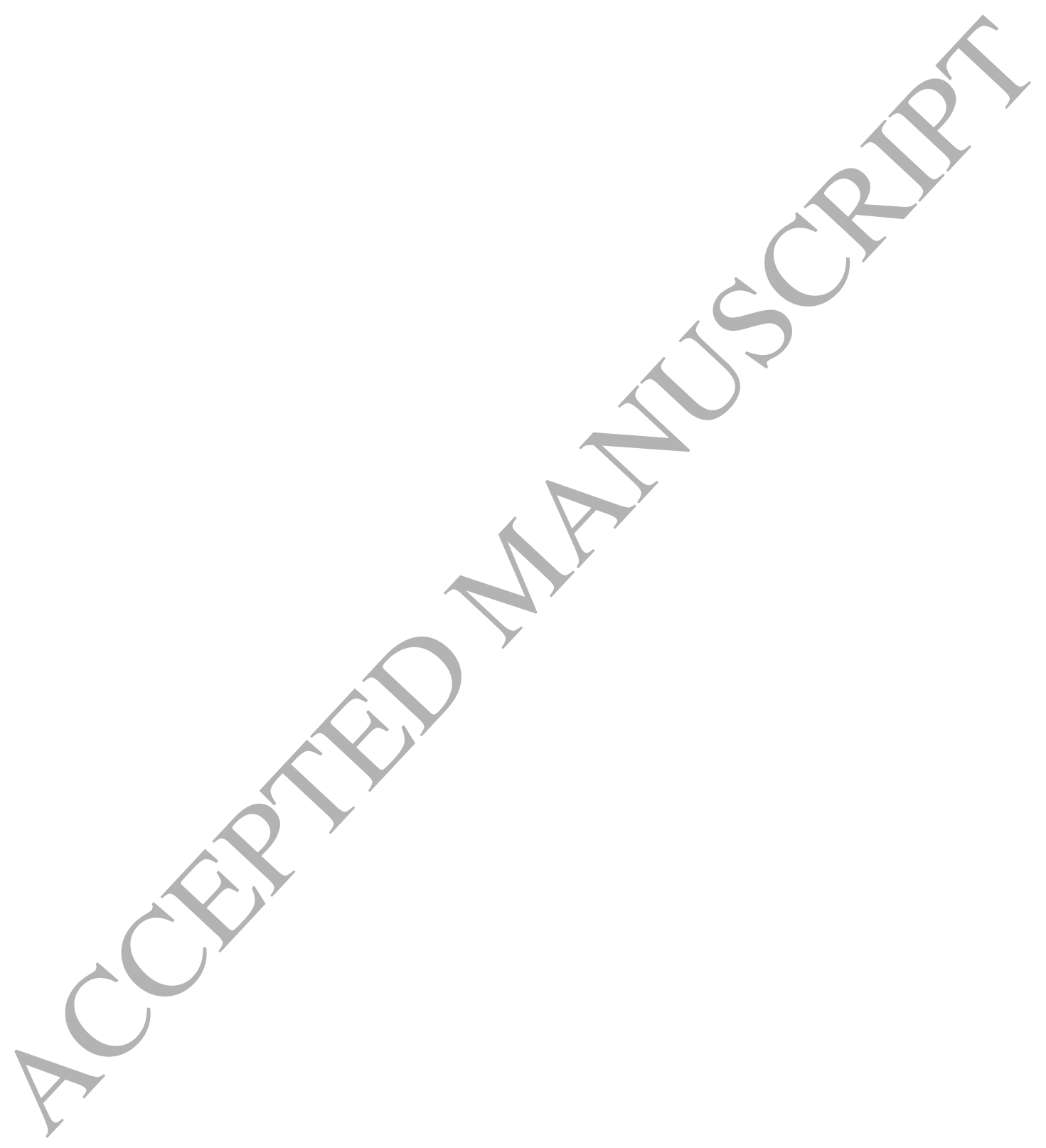




\section{References}

1. American Society of Anesthesiologists Task Force on Perioperative Blood Management. Practice guidelines for perioperative blood management: an updated report by the American Society of Anesthesiologists Task Force on Perioperative Blood Management. Anesthesiology $2015 ; 122: 241-275$.

2. SFAR - Société Française d'Anesthésie et de Réanimation. Transfusion de globules rouges homologues : produits, indications alternatives. 2015. Available at http://sfar.org/transfusionde-globules-rouges-homologues-produits-indications-alternatives/

3. Carson JL, Guyatt G, Heddle NM, et al. Clinical Practice Guidelines From the AABB: red blood cell transfusion thresholds and storage. JAMA 2016;316:2025-2035.

4. Ferraris VA, Ferraris SP, Saha SP, et a1. Perioperative Blood Transfusion and Blood Conservation in Cardiac Surgery: The Society of Thoracic Surgeons and The Society of Cardiovascular Anesthesiologists Clinical Practice Guideline. Ann Thorac Surg 2007;83:S27-86.

5. Ferraris VA, Brown JR, Despotis GJ, et al. 2011 Update to The Society of Thoracic Surgeons and the Society of Cardiovascular Anesthesiologists Blood Conservation Clinical Practice Guidelines. Ann Thorac Surg 2011;91:944-982.

6. Moskowitz DM, Klein JJ, Shander A, et al. Predictors of transfusion requirements for cardiac surgical procedures at a blood conservation center. Ann Thorac Surg 2004;77:626-634.

7. Santo LSD, Amarelli C, Corte AD, et al. Blood transfusion after on-pump coronary artery bypass grafting: focus on modifiable risk factors. Eur J Cardiothorac Surg 2013;43:359-366. 
8. Surgenor SD, Kramer RS, Olmstead EM, et al. The Association of Perioperative Red Blood Cell Transfusions and Decreased Long-Term Survival After Cardiac Surgery. Anesth Analg 2009;108:1741-1746.

9. Koch CG, Li L, Duncan Al, Mihaljevic T, et al. Morbidity and mortality risk associated with red blood cell and blood-component transfusion in isolated coronary artery bypass grafting. Crit Care Med 2006;34:1608-1616.

10. Paone G, Likosky DS, Brewer R, et al. Transfusion of 1 and 2 Units of Red Blood Cells Is Associated With Increased Morbidity and Mortality. Ann Thorac Surg 2014;97:87-94.

11. McQuilten ZK, Andrianopoulos N, Wood EM, et al.Transfusíon practice varies widely in cardiac surgery: Results from a national registry. J Thorac Cardiov Sur 2014;147:1684-1690.

12. van Straten AHM, Kats S, Bekker MWA, et al. Risk Factors for Red Blood Cell Transfusion After Coronary Artery Bypass Graft Surgery. J Cardiothor Vasc An 2010;24:413-417.

13. Murphy GJ, Pike K, Rogers CA, et al. Liberal or Restrictive Transfusion after Cardiac Surgery. N Engl J Med 2015;372:997-1008.

14. Ferraris VA. Blood transfusion in cardiac surgery: who should get transfused? Lancet Haematol $2015 ; 2: 510-511$.

15. Bennett-Guerrero $\mathrm{E}$, Zhao $\mathrm{Y}, \mathrm{O}^{\prime} \mathrm{Brien} \mathrm{SM}$, et al. Variation in use of blood transfusion in coronary artery bypass graft surgery. JAMA 2010;304:1568-1575.

16. Horvath KA, Acker MA, Chang H, et al. Blood Transfusion and Infection After Cardiac Surgery. Ann Thorac Surg 2013;95:2194-2201.

17. Scott B, Seifert F, Grimson R. Blood transfusion is associated with increased resource utilisation, morbidity and mortality in cardiac surgery. Ann Card Anaesth 2008;11:15. 
18. Koch CG, Li L, Duncan Al, et al. Transfusion in Coronary Artery Bypass Grafting is Associated with Reduced Long-Term Survival. Ann Thorac Surg 2006;81:1650-1657.

19. Ad N, Holmes SD, Massimiano PS, et al. Operative risk and preoperative hematocrit in bypass graft surgery: role of gender and blood transfusion. Cardiovasc Revascularization 2015;16:397400.

20. Murphy GJ, Reeves BC, Rogers CA, et al. Increased mortality, postoperative morbidity, and cost after red blood cell transfusion in patients having cardiac surgery. Circulation 2007;116:25442552.

21. Goodnough LT, Maniatis A, Earnshaw P, et al. Detection, evaluation, and management of preoperative anaemia in the elective orthopaedic surgical patient: NATA guidelines. $\mathrm{Br} \mathrm{J}$ Anaesth 2011;106:13-22.

22. Karkouti K, Wijeysundera DN, Beattie WS, Reducing Bleeding in Cardiac Surgery (RBC) Investigators. Risk associated with preoperative anemia in cardiac surgery: a multicenter cohort study. Circulation 2008;117:478-484.

23. Kulier A, Levin J, Moser R, et al. Impact of preoperative anemia on outcome in patients undergoing coronary artery bypass graft surgery. Circulation 2007;116:471-479.

24. Musallam KM, Tamim HM, Richards T, et al. Preoperative anaemia and postoperative outcomes in non-cardiac surgery: a retrospective cohort study. Lancet 2011;378:1396-1407.

25. Williams ML, He X, Rankin JS, et al. Preoperative hematocrit is a powerful predictor of adverse outcomes in coronary artery bypass graft surgery: a report from the Society of Thoracic Surgeons Adult Cardiac Surgery Database. Ann Thorac Surg 2013;96:1628-1634. 
26. Ponikowski P, Voors AA, Anker SD, et al. 2016 ESC Guidelines for the diagnosis and treatment of acute and chronic heart failure: The Task Force for the diagnosis and treatment of acute and chronic heart failure of the European Society of Cardiology (ESC) Developed with the special contribution of the Heart Failure Association (HFA) of the ESC. Eur Heart J 2016;37:2129-2200.

27. Kassebaum NJ, Jasrasaria R, Naghavi M, et al. A systematic analysis of global anemia burden from 1990 to 2010. Blood 2014;123:615-624.

28. Klip IT, Comin-Colet J, Voors AA, et al. Iron deficiency in chronic heart failure: an international pooled analysis. Am Heart J 2013;165:575-582.

29. Piednoir P, Allou N, Driss F, et al. Preoperative iron deficiency increases transfusion requirements and fatigue in cardiac surgery patients: a prospective observational study. Eur J Anaesthesiol 2011;28:796-801.

30. McDonagh T, Macdougall IC. Iron therapy for the treatment of iron deficiency in chronic heart failure: intravenous or oral? Eur J Heart Fail 2015;17:248-262.

31. Gross I, Seifert B, Hofmann A, et al. Patient blood management in cardiac surgery results in fewer transfusions and better outcome. Transfusion 2015;55:1075-1081.

32. Lasocki $\mathrm{S}$, Longrois $\mathrm{D}$, Montravers $\mathrm{P}$, et al. Hepcidin and anemia of the critically ill patient: bench to bedside. Anesthesiology 2011;114:688-694.

33. Ganz T, Nemeth E. Hepcidin and iron homeostasis. Biochim Biophys Acta 2012;1823:1434-1443.

34. Myles PS, Smith JA, Forbes A, et al. Tranexamic acid in patients undergoing coronary-artery surgery. N Engl J Med 2017;376:136-148. 
35. Koch CG, Li L, Duncan Al, et al. Morbidity and mortality risk associated with red blood cell and blood-component transfusion in isolated coronary artery bypass grafting. Crit Care Med 2006;34:1608-1616.

36. Hajjar LA, Vincent J-L, Galas FRBG, et al. Transfusion Requirements After Cardiac Surgery: The TRACS randomized controlled trial. JAMA 2010;304:1559-1567.

37. Karkouti K, Wijeysundera DN, Yau TM, et al. Acute kidney injury after cardiac surgery: focus on modifiable risk factors. Circulation 2009;119:495-502.

38. Shander A, Van Aken H, Colomina MJ, et al. Patient blood management in Europe. Br J Anaesth 2012;109:55-68.

39. Lasocki S, Krauspe R, von Heymann C, et al. PREPARE: the prevalence of perioperative anaemia and need for patient blood management in elective orthopaedic surgery: a multicentre, observational study. Eur J Anaesthesiol 2015;32:160-167.

40. Pearse BL, Smith I, Faulke D, et al. Protocol guided bleeding management improves cardiac surgery patient outcomes. Vox Sang 2015;109:267-279.

41. Lasocki S, Dupre P, Rineau E. Indications du fer et de l'érythropoiétine en anesthésie. Conférence d'actualisation SFAR 2016.

42. Munoz $M$, Acheson $A G$, Auerbach $M$, et al. International consensus statement on the perioperative management of anaemia and iron deficiency. Anaesthesia 2017;72:233-247. 


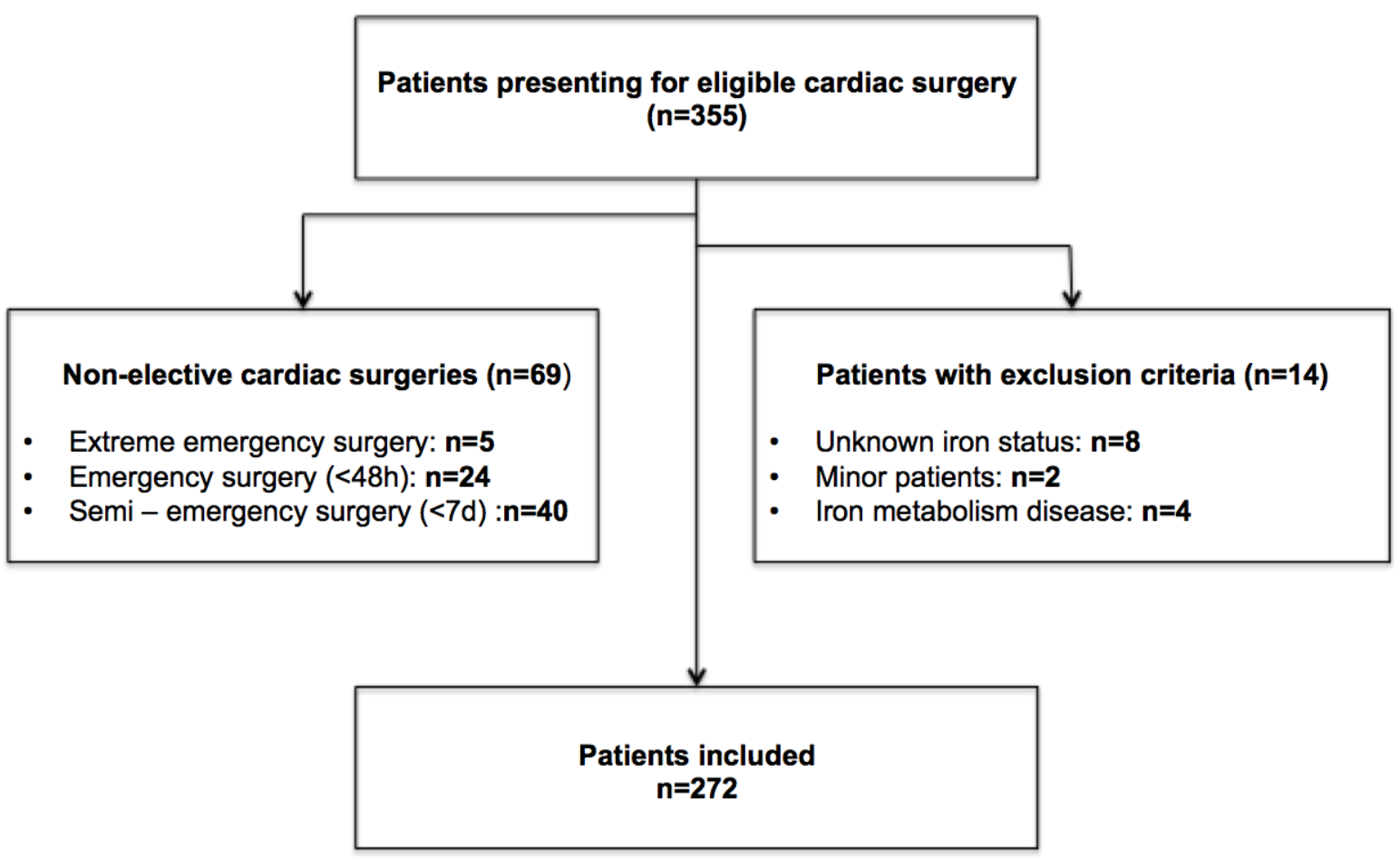

Figure 1. Flowchart of the study

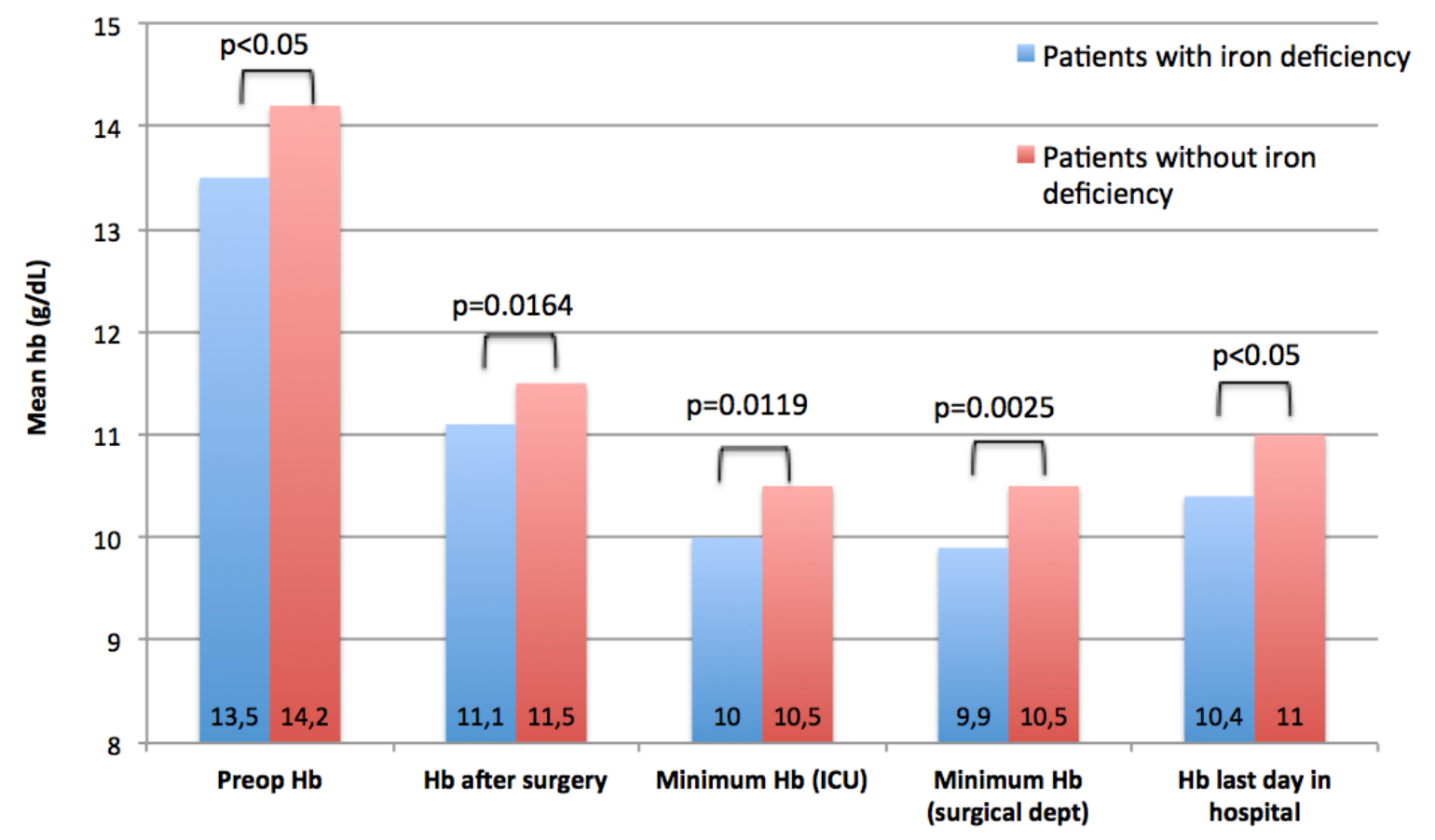

Figure 2. Hemoglobin levels during the hospital stay 


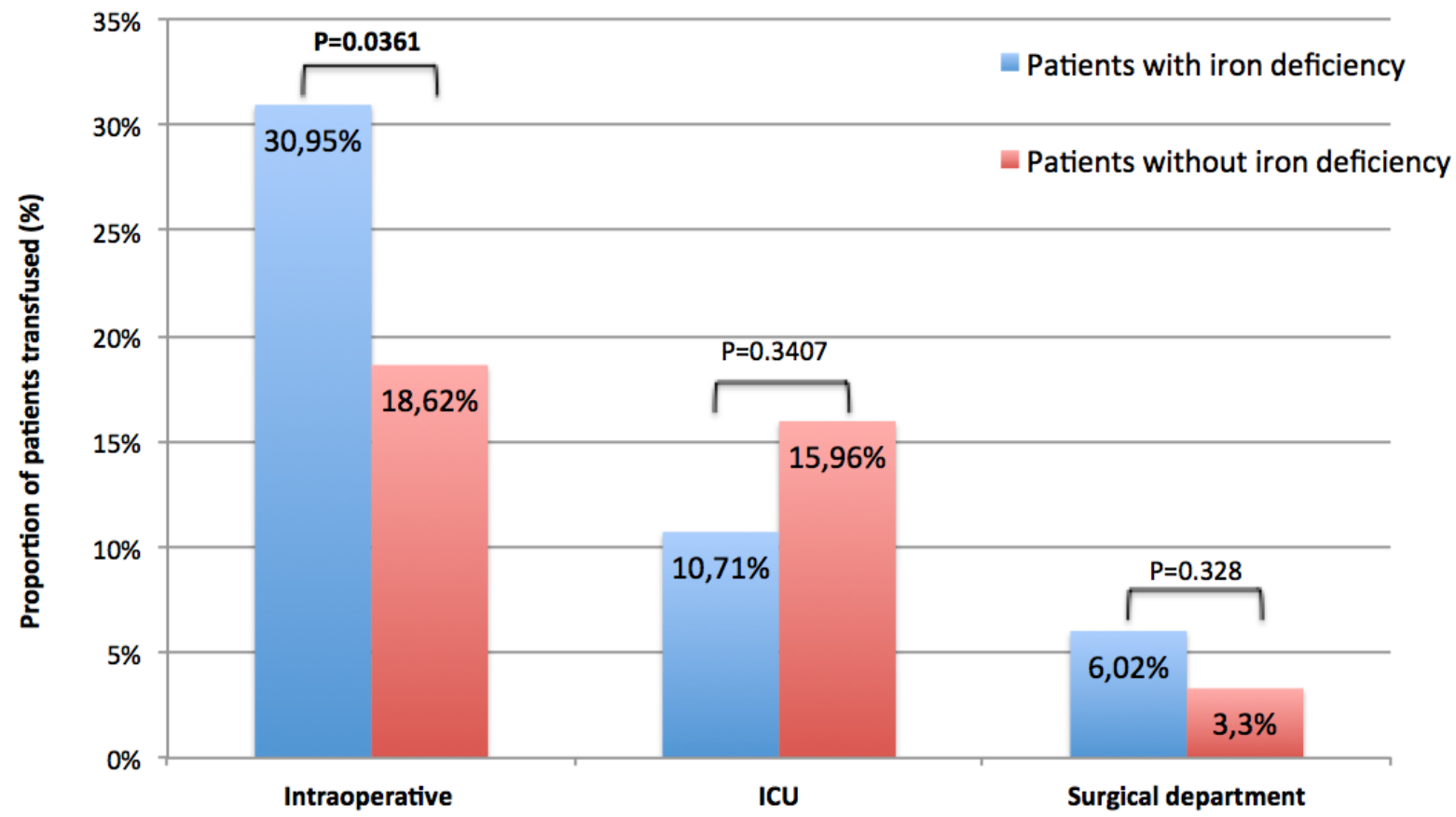

Figure 3. Transfusion rates during the hospital stay

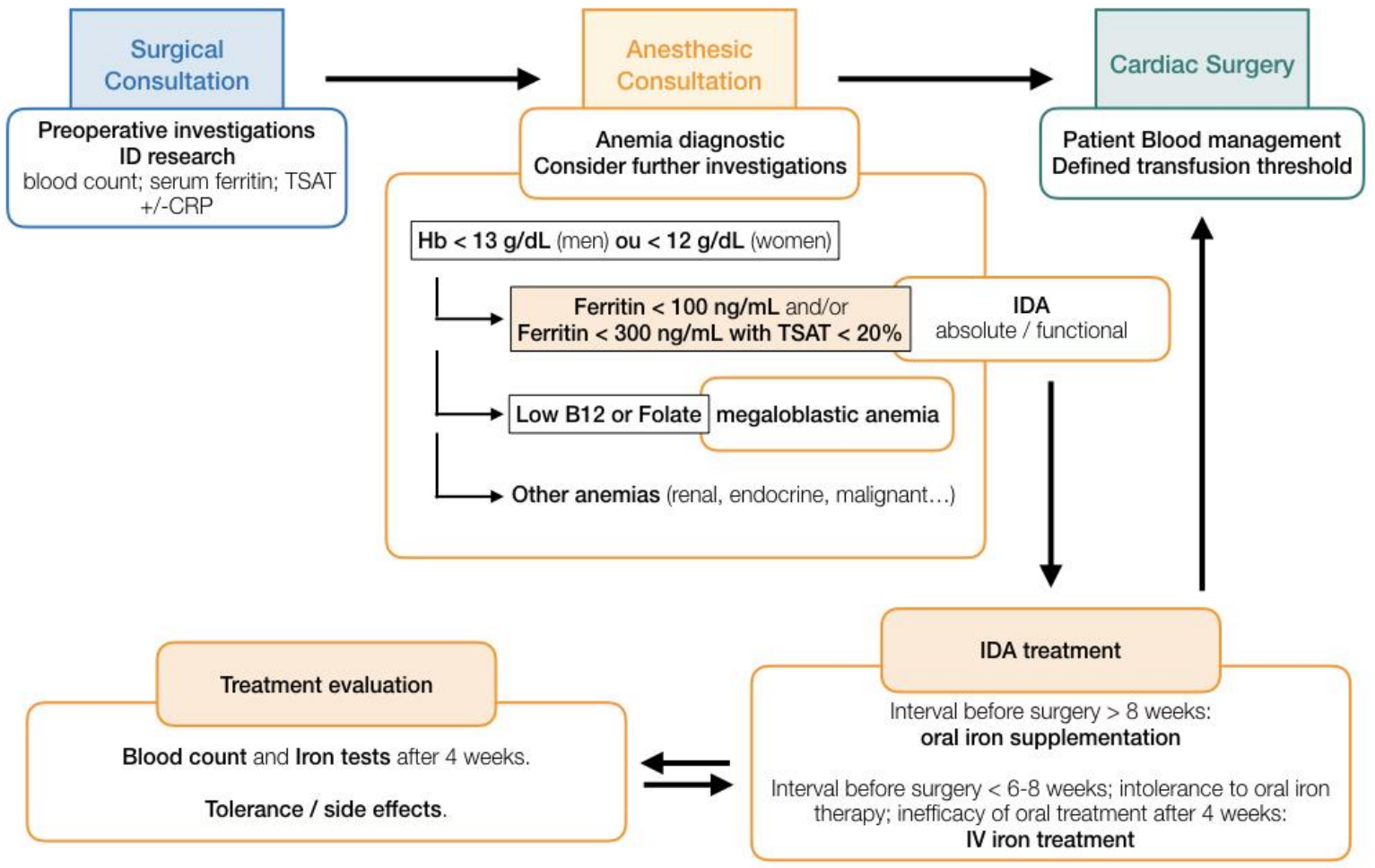

Figure 4. Proposition for a clinical pathway to address iron deficiency 
Table 1. Population characteristics

\begin{tabular}{|c|c|c|c|c|}
\hline Variable & $\begin{array}{l}\text { Population } \\
\quad(\mathrm{n}=272)\end{array}$ & $\begin{array}{l}\text { Patients with } \\
\text { iron deficiency } \\
(n=84)\end{array}$ & $\begin{array}{l}\text { Patients without } \\
\text { iron deficiency } \\
(n=188)\end{array}$ & $\mathbf{p}$ \\
\hline Age (years) * & $67 \pm 11$ & $66 \pm 13$ & $67 \pm 10$ & 0.50 \\
\hline $\begin{array}{l}\text { Sex } \\
\text { Male } \\
\text { Female }\end{array}$ & $\begin{array}{c}186(68 \%) \\
86(32 \%)\end{array}$ & $\begin{array}{l}43(51 \%) \\
41(49 \%)\end{array}$ & $\begin{array}{c}143(76 \%) \\
45(24 \%)\end{array}$ & $p<0.05$ \\
\hline BMI $\left(\mathrm{kg} / \mathrm{m}^{2}\right)$ * & $27 \pm 4$ & $27 \pm 5$ & $27 \pm 4$ & 0.27 \\
\hline $\begin{array}{c}\text { ASA score • } \\
\text { I } \\
\text { II } \\
\text { III } \\
\text { IV }\end{array}$ & $\begin{array}{c}1(0 \%) \\
7(3 \%) \\
229(84 \%) \\
35(13 \%) \\
\end{array}$ & $\begin{array}{c}1(1 \%) \\
2(2 \%) \\
67(80 \%) \\
14(17 \%) \\
\end{array}$ & $\begin{array}{c}5(3 \%) \\
162(86 \%) \\
21(11 \%) \\
\end{array}$ & \\
\hline $\begin{array}{l}\text { Smoking • } \\
\text { Active } \\
\text { Weaned }\end{array}$ & $\begin{array}{c}25(9 \%) \\
101(37 \%)\end{array}$ & $\begin{array}{c}8(10 \%) \\
26(31 \%)\end{array}$ & $\begin{array}{c}17(9 \%) \\
75(40 \%)\end{array}$ & 0.36 \\
\hline High blood pressure • & $172(63 \%)$ & $59(70 \%)$ & $113(60 \%)$ & 0.14 \\
\hline Dyslipidemia • & $135(50 \%)$ & $38(45 \%)$ & $97(52 \%)$ & 0.40 \\
\hline Arteriopathy $\bullet$ & $22(8 \%)$ & $11(13 \%)$ & $11(6 \%)$ & 0.07 \\
\hline Angora $•$ & $73(27 \%)$ & $16(19 \%)$ & $57(30 \%)$ & 0.07 \\
\hline COPD• & $22(8 \%)$ & $10(12 \%)$ & $12(6 \%)$ & 0.19 \\
\hline Asthma • & $11(4 \%)$ & $3(4 \%)$ & $8(4 \%)$ & 1 \\
\hline $\begin{array}{c}\text { Diabetes } \\
\text { with insulin } \\
\text { without insulin }\end{array}$ & $\begin{array}{l}2(4 \%) \\
0(11 \%)\end{array}$ & $\begin{array}{c}7(8 \%) \\
11(13 \%)\end{array}$ & $\begin{array}{c}5(3 \%) \\
19(10 \%)\end{array}$ & 0.07 \\
\hline Atrial fibrillation • & $44(16 \%)$ & $18(21 \%)$ & $26(14 \%)$ & 0.16 \\
\hline $\begin{array}{c}\text { CRF } \cdot \\
\begin{array}{c}\text { Preoperative creatinine ser } \\
\text { level }(\mu \mathrm{mol} / \mathrm{L})\end{array}\end{array}$ & $\begin{array}{l}43(16 \%) \\
88 \pm 27\end{array}$ & $\begin{array}{l}15(18 \%) \\
84 \pm 25\end{array}$ & $\begin{array}{l}28(15 \%) \\
90 \pm 29\end{array}$ & $\begin{array}{l}0.66 \\
0.08\end{array}$ \\
\hline
\end{tabular}

${ }^{*}$ Mean + - standard deviation $\cdot$ Number of patients (percentage)

BMI: body mass index. ASA: American Society of Anesthesiologists. COPD: chronic obstructive pulmonary disease. CRF:

chronic renal failure defined by a glomerular filtration rate $<60 \mathrm{~mL} / \mathrm{min} / 1.73 \mathrm{~m} 2$. 
Table 2. Preoperative cardiological evaluation

\begin{tabular}{|c|c|c|c|c|}
\hline Variable & $\begin{array}{l}\text { Population } \\
(\mathrm{n}=272)\end{array}$ & $\begin{array}{c}\text { Patients with } \\
\text { iron deficiency } \\
(n=84)\end{array}$ & $\begin{array}{c}\text { Patients without } \\
\text { iron deficiency } \\
(n=188)\end{array}$ & p \\
\hline $\operatorname{LVEF}(\%)$ * & $61 \pm 10$ & $62 \pm 11$ & $60 \pm 10$ & 0.32 \\
\hline Pulmonary hypertension • & 49 (18\%) & $16(19 \%)$ & $33(18 \%)$ & 0.90 \\
\hline $\begin{array}{c}\text { Dyspnea: NYHA grading • } \\
\text { I } \\
\text { II } \\
\text { III } \\
\text { IV }\end{array}$ & $\begin{array}{c}67(25 \%) \\
144(53 \%) \\
55(20 \%) \\
4(2 \%)\end{array}$ & $\begin{array}{c}17(20 \%) \\
42(50 \%) \\
23(27 \%) \\
1(1 \%)\end{array}$ & $\begin{array}{c}50(27 \%) \\
102(54 \%) \\
32(17 \%) \\
3(2 \%)\end{array}$ & 0.27 \\
\hline $\begin{array}{c}\text { Preoperative coronarography } \\
\text { Missing } \\
\text { Non-significant lesions } \\
\text { Significant lesions } \\
\text { Normal }\end{array}$ & $\begin{array}{c}3(1 \%) \\
44(16 \%) \\
124(46 \%) \\
101(37 \%)\end{array}$ & $\begin{array}{c}2(2 \%) \\
17(20 \%) \\
33(39 \%) \\
32(39 \%)\end{array}$ & $\begin{array}{l}27(14 \%) \\
91(48 \%) \\
69(37 \%)\end{array}$ & 0.21 \\
\hline $\begin{array}{c}\text { Preoperative therapy } \\
\text { Aspirin } \\
\text { Ticagrelor } \\
\text { NOAC }\end{array}$ & $\begin{array}{c}147(54 \%) \\
1(0 \%) \\
2(1 \%)\end{array}$ & & $\begin{array}{c}106(56 \%) \\
1(1 \%) \\
1(1 \%)\end{array}$ & 0.54 \\
\hline
\end{tabular}

* Mean +/- standard deviation • Number of patients (percentage)

LEVF: left ventricular ejection fraction. NYHA: New York Heart Association. NOAC: non-vitamin K antagonist oral anticoagulants. 
Table 3. Surgical data

\begin{tabular}{|c|c|c|c|c|}
\hline Variable & $\begin{array}{l}\text { Population } \\
(\mathrm{n}=272)\end{array}$ & $\begin{array}{c}\text { Patients with } \\
\text { iron deficiency } \\
(\mathrm{n}=84)\end{array}$ & $\begin{array}{c}\begin{array}{c}\text { Patients without } \\
\text { iron deficiency } \\
(n=188)\end{array} \\
\end{array}$ & $\mathbf{p}$ \\
\hline $\begin{array}{c}\text { Surgery } \\
\text { Valve } \\
\text { Coronary bypass } \\
\text { Combined surgery } \\
\text { Other }\end{array}$ & $\begin{array}{c}115(42 \%) \\
89(33 \%) \\
50(18 \%) \\
18(7 \%)\end{array}$ & $\begin{array}{c}36(43 \%) \\
19(23 \%) \\
22(26 \%) \\
7(8 \%)\end{array}$ & $\begin{array}{c}79(42 \%) \\
70(37 \%) \\
28(15 \%) \\
11(6 \%)\end{array}$ & $\begin{array}{c}0.03 \\
1 \\
0.03 \\
0.04 \\
0.62\end{array}$ \\
\hline $\begin{array}{c}\text { Coronary bypass }(n=110): \\
\text { Number of bypass * }\end{array}$ & $2.1 \pm 0.8$ & $1.8 \pm 0.9$ & $2 \pm 0.0$ & 0.03 \\
\hline $\begin{array}{l}\text { Valve }(n=147) \cdot \\
\text { Biological } \\
\text { Mechanical }\end{array}$ & $\begin{array}{l}135(92 \%) \\
12(8 \%)\end{array}$ & $\begin{array}{l}49(87 \%) \\
7(13 \%)\end{array}$ & & 0.21 \\
\hline $\begin{array}{l}\text { Reoperation }(n=8) \bullet \\
\text { Redux } \\
\text { Tridux }\end{array}$ & $\begin{array}{l}6(2 \%) \\
2(1 \%)\end{array}$ & $\begin{array}{l}2(2 \%) \\
1(1 \%)\end{array}$ & $\begin{array}{l}4(2 \%) \\
1(1 \%)\end{array}$ & 0.84 \\
\hline $\begin{array}{c}\text { Cardiopulmonary bypass } \\
\text { Length of CPB (min) * } \\
\text { Length of aortic cross-clamp (min) * }\end{array}$ & $\begin{array}{l}256(94 \%) \\
88 \pm 38 \\
69 \pm 30\end{array}$ & $\begin{array}{l}79,(94 \%) \\
92 \pm 40 \\
73 \pm 29\end{array}$ & $\begin{array}{l}177(94 \%) \\
87 \pm 37 \\
68 \pm 30\end{array}$ & $\begin{array}{c}1 \\
0.28 \\
0.24\end{array}$ \\
\hline Beating-heart surgeries & $16(6 \%)$ & $5(6 \%)$ & $11(6 \%)$ & 1 \\
\hline Circulatory arrest - & $15(6 \%)$ & $4(5 \%)$ & $11(6 \%)$ & 1 \\
\hline
\end{tabular}

* Mean + -- standard deviation • Number of patients (percentage)

Redux: first reoperation after one cardiac surgery. Tridux: seçond reoperation. CPB: cardiopulmonary bypass. 
Table 4. Biological data

\begin{tabular}{|c|c|c|c|c|}
\hline Variable & $\begin{array}{l}\text { Population } \\
(n=272)\end{array}$ & $\begin{array}{c}\text { Patients with } \\
\text { iron deficiency } \\
(\mathrm{n}=84)\end{array}$ & $\begin{array}{c}\text { Patients without } \\
\text { iron deficiency } \\
(n=188)\end{array}$ & p \\
\hline $\begin{array}{c}\text { Preoperative } \\
\text { Hemoglobin }(\mathrm{g} / \mathrm{dL}) \\
\text { Anemia } \bullet \\
\text { Serum ferritin }(\mathrm{ng} / \mathrm{mL})\end{array}$ & $\begin{array}{c}14 \pm 1.4 \\
35(13 \%) \\
262 \pm 210 \\
27 \pm 12\end{array}$ & $\begin{array}{l}13.5 \pm 1.5 \\
16(19 \%) \\
92 \pm 61 \\
20 \pm 12\end{array}$ & $\begin{array}{c}14.2 \pm 1.3 \\
19(10 \%) \\
338 \pm 208 \\
30 \pm 11\end{array}$ & $\begin{array}{l}p<0.05 \\
0.07 \\
p<0.05 \\
p<0.05\end{array}$ \\
\hline$\frac{\text { Intraoperative }}{\text { Hematocrit }^{*}}$ & $29 \pm 4$ & $27 \pm 4$ & & $p<0.05$ \\
\hline $\begin{array}{c}\text { Postoperative (ICU) } \\
\text { First hemoglobin }(\mathrm{g} / \mathrm{dL}) \\
\text { Minimum hemoglobin }(\mathrm{g} / \mathrm{dL})\end{array}$ & $\begin{array}{l}11.4 \pm 1.3 \\
10.4 \pm 1.7 \\
\end{array}$ & $\begin{array}{c}11.1 \pm 1.3 \\
10 \pm 1.6 \\
\end{array}$ & $\begin{array}{l}11.5 \pm 1.3 \\
10.6 \pm 1.7 \\
\end{array}$ & $\begin{array}{l}0.02 \\
0.01\end{array}$ \\
\hline $\begin{array}{c}\text { Postoperative (surgical ward) } \\
\text { Minimum hemoglobin }(\mathrm{g} / \mathrm{dL})^{*} \\
\text { Hemoglobin on the day out }(\mathrm{g} / \mathrm{dL}) \text { * }\end{array}$ & $\begin{array}{l}10.3 \pm 1.5 \\
10.8 \pm 1.3\end{array}$ & $\begin{array}{c}9.9 \pm 1.3 \\
10.4 \pm 1.3\end{array}$ & $11 \pm 1.3$ & $\begin{array}{l}p<0.05 \\
p<0.05\end{array}$ \\
\hline
\end{tabular}

* Mean + - - standard deviation • Number of patients (percentage)

ICU: Intensive Care Unit 
Table 5. Transfusion data.

\begin{tabular}{|c|c|c|c|c|}
\hline Variable & $\begin{array}{l}\text { Population } \\
(n=272)\end{array}$ & $\begin{array}{c}\text { Patients with iron } \\
\text { deficiency } \\
(n=84)\end{array}$ & $\begin{array}{c}\text { Patients without } \\
\text { iron deficiency } \\
(n=188)\end{array}$ & $\mathbf{p}$ \\
\hline$\frac{\text { Hospital stay }}{\text { Patients transfused }}$ & $88(33 \%)$ & $33(39 \%)$ & $55(30 \%)$ & 0.15 \\
\hline $\begin{array}{l}\text { RBC (number of unit) * } \\
\text { RBC (proportion) }\end{array}$ & $\begin{array}{l}0.2 \pm 0.5 \\
65(25 \%)\end{array}$ & $\begin{array}{l}0.3 \pm 0.5 \\
25(30 \%)\end{array}$ & $\begin{array}{l}0.2 \pm 0.5 \\
40(22 \%)\end{array}$ & $\begin{array}{l}0.25 \\
0.20\end{array}$ \\
\hline $\begin{array}{l}\text { FFP (number of unit) * } \\
\text { FFP (proportion) }\end{array}$ & $\begin{array}{l}0.1 \pm 0.4 \\
30(11 \%)\end{array}$ & $\begin{array}{l}0.1 \pm 0.3 \\
7(8 \%)\end{array}$ & $\begin{array}{l}0.2 \pm 0.5 \\
23(13 \%)\end{array}$ & $\begin{array}{l}0.13 \\
0.42\end{array}$ \\
\hline $\begin{array}{l}\text { Platelets (number of unit) * } \\
\text { Platelets (proportion) }\end{array}$ & $\begin{array}{l}0.1 \pm 0.1 \\
32(12 \%)\end{array}$ & $\begin{array}{c}0 \pm 0.1 \\
10(12 \%)\end{array}$ & $\begin{array}{l}0.1 \pm 0.1 \\
22(12 \%)\end{array}$ & $\begin{array}{c}0.56 \\
1\end{array}$ \\
\hline $\begin{array}{c}\text { Fibrinogen }(\mathrm{g})^{*} \\
\text { Fibrinogen (proportion) }\end{array}$ & $\begin{array}{l}0.2 \pm 0.4 \\
34(13 \%)\end{array}$ & $\begin{array}{c}0.1 \pm 0.3 \\
6(7 \%)\end{array}$ & $\begin{array}{l}0.2 \pm 0.5 \\
28(15 \%)\end{array}$ & $\begin{array}{l}0.02 \\
0.11\end{array}$ \\
\hline$\frac{\text { Intraoperative }}{\text { Patients transfused }}$ & $61(22 \%)$ & 26 (3 & $35(19 \%)$ & 0.04 \\
\hline $\begin{array}{l}\text { RBC (number of unit) * } \\
\text { RBC (proportion) }\end{array}$ & $\begin{array}{c}0.3 \pm 1 \\
41(15 \%)\end{array}$ & & $\begin{array}{l}0.3 \pm 0.9 \\
22(12 \%)\end{array}$ & $\begin{array}{l}0.07 \\
\mathbf{0 . 0 3}\end{array}$ \\
\hline $\begin{array}{l}\text { FFP (number of unit) * } \\
\text { FFP (proportion) }\end{array}$ & $\begin{array}{c}0.3 \pm 1 \\
26(10 \%)\end{array}$ & & $\begin{array}{l}0.3 \pm 0.9 \\
19(10 \%)\end{array}$ & $\begin{array}{l}0.98 \\
0.80\end{array}$ \\
\hline $\begin{array}{l}\text { Platelets (number of unit) * } \\
\text { Platelets (proportion) }\end{array}$ & $\begin{array}{l}0.1 \pm 0.4 \\
30(11 \%)\end{array}$ & $\begin{array}{l}0.1 \pm 0.4 \\
9(11 \%)\end{array}$ & $\begin{array}{l}0.1 \pm 0.4 \\
21(11 \%)\end{array}$ & $\begin{array}{c}0.94 \\
1\end{array}$ \\
\hline $\begin{array}{c}\text { Fibrinogen }(\mathrm{g}) \\
\text { Fibrinogen (proportion) }\end{array}$ & $\begin{array}{c}1.1 \pm 0.5 \\
13(5 \%)\end{array}$ & $\begin{array}{c}0.1 \pm 0.4 \\
3(4 \%)\end{array}$ & $\begin{array}{c}0.1 \pm 0.5 \\
10(5 \%)\end{array}$ & $\begin{array}{l}0.48 \\
0.76\end{array}$ \\
\hline Retransfusion $(\mathrm{mL})$ * & 31 & $623 \pm 353$ & $619 \pm 296$ & 0.93 \\
\hline Patients $\frac{\text { ICU }}{\operatorname{transf}}$ & & $9(11 \%)$ & $30(16 \%)$ & 0.34 \\
\hline $\begin{array}{l}\text { RBC (number of } \\
\text { RBC (proportio }\end{array}$ & $\begin{array}{c}0.3 \pm 1 \\
33(12 \%)\end{array}$ & $\begin{array}{l}0.2 \pm 0.7 \\
9(11 \%)\end{array}$ & $\begin{array}{l}0.3 \pm 1.1 \\
24(13 \%)\end{array}$ & $\begin{array}{l}0.26 \\
0.78\end{array}$ \\
\hline $\begin{array}{l}\text { FFP (number of } \\
\text { FFP (proportio }\end{array}$ & $\begin{array}{l}0.2 \pm 0.9 \\
14(6 \%)\end{array}$ & $\begin{array}{l}0 \pm 0.2 \\
2(2 \%)\end{array}$ & $\begin{array}{l}0.2 \pm 1 \\
12(6 \%)\end{array}$ & $\begin{array}{l}\mathbf{0 . 0 3} \\
0.24\end{array}$ \\
\hline $\begin{array}{l}\text { Platelets (number of unit * } \\
\text { Platelets (proportion) • }\end{array}$ & $\begin{array}{c}0.1 \pm 0.3 \\
10(4 \%)\end{array}$ & $\begin{array}{l}0 \pm 0.2 \\
2(2 \%)\end{array}$ & $\begin{array}{l}0.1 \pm 0.3 \\
8(4 \%)\end{array}$ & $\begin{array}{l}0.22 \\
0.73\end{array}$ \\
\hline $\begin{array}{c}\text { Fibrinogen }(\mathrm{g}) \\
\text { Fibrinogen (proportion) }\end{array}$ & $\begin{array}{l}0.2 \pm 0.7 \\
21(8 \%)\end{array}$ & $\begin{array}{c}0.1 \pm 0.4 \\
3(4 \%)\end{array}$ & $\begin{array}{l}0.3 \pm 0.8 \\
18(10 \%)\end{array}$ & $\begin{array}{l}0.02 \\
0.14\end{array}$ \\
\hline Tranexamic acid $(\mathrm{g})$ * & $0.2 \pm 0.8$ & $0.2 \pm 0.8$ & $0.2 \pm 0.9$ & 0.87 \\
\hline
\end{tabular}




\begin{tabular}{|c|c|c|c|c|}
\hline$\frac{\text { Surgical department }}{\text { Patients transfused }}$ & $11(4 \%)$ & $5(6 \%)$ & $6(3 \%)$ & 0.33 \\
\hline $\begin{array}{l}\text { RBC (number of unit) * } \\
\text { RBD (proportion) }\end{array}$ & $\begin{array}{l}0.1 \pm 0.4 \\
11(4 \%)\end{array}$ & $\begin{array}{c}0.1 \pm 0.5 \\
5(6 \%)\end{array}$ & $\begin{array}{c}0.1 \pm 0.4 \\
6(3 \%)\end{array}$ & $\begin{array}{l}0.41 \\
0.33\end{array}$ \\
\hline $\begin{array}{l}\text { FFP (number of unit) * } \\
\text { FFP (proportion) }\end{array}$ & $\begin{array}{l}- \\
-\end{array}$ & $\begin{array}{l}- \\
-\end{array}$ & $\begin{array}{l}- \\
-\end{array}$ & $\begin{array}{l}- \\
-\end{array}$ \\
\hline $\begin{array}{l}\text { Platelets (number of unit) * } \\
\text { Platelets (proportion) }\end{array}$ & $\begin{array}{l}- \\
-\end{array}$ & $\begin{array}{l}- \\
-\end{array}$ & $\begin{array}{l}- \\
-\end{array}$ & $\begin{array}{l}- \\
-\end{array}$ \\
\hline
\end{tabular}

* Mean +/- standard deviation. - Number of patients (percentage). RBC: red blood cell. FFP: fresh frozen plasma.

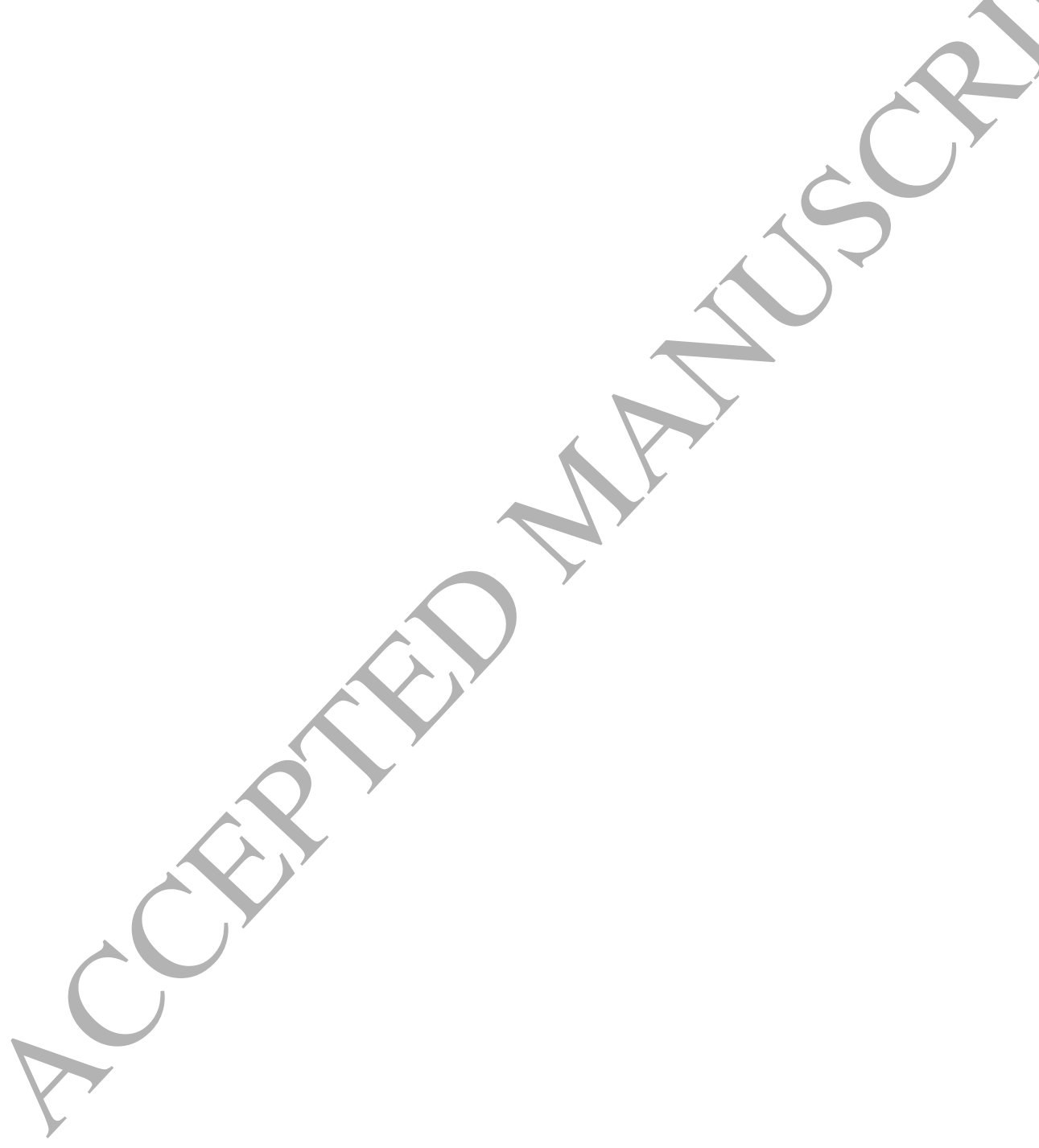


Table 6. Proportion of patients receiving red blood cells transfusion.

\begin{tabular}{|c|c|c|c|c|}
\hline Variable & $\begin{array}{c}\text { Population } \\
(\mathbf{n = 2 6 5 )}\end{array}$ & $\begin{array}{c}\text { Patients with iron } \\
\text { deficiency } \\
(\mathbf{n}=83)\end{array}$ & $\begin{array}{c}\text { Patients without } \\
\text { iron deficiency } \\
(\mathbf{n = 1 8 2})\end{array}$ & p \\
\hline$\underline{\text { Number of RBC }}$ & units & & $142(78 \%)$ & 0.41 \\
$\mathbf{0}$ & $200(76 \%)$ & $68(70 \%)$ & $13(7 \%)$ \\
$\mathbf{1}$ & $19(7 \%)$ & $11(13 \%)$ & $16(9 \%)$ \\
$\mathbf{2}$ & $27(10 \%)$ & $8(10 \%)$ & $11(6 \%)$ & \\
\hline
\end{tabular}

- Number of patients (percentage)

RBC: red blood cell. 
Table 7. Postoperative data.

\begin{tabular}{|c|c|c|c|c|}
\hline Variable & $\begin{array}{l}\text { Population } \\
(\mathrm{n}=272)\end{array}$ & $\begin{array}{c}\text { Patients with } \\
\text { iron deficiency } \\
(n=84)\end{array}$ & $\begin{array}{c}\text { Patients without } \\
\text { iron deficiency } \\
(n=188)\end{array}$ & $\mathbf{p}$ \\
\hline Postoperative bleeding $(24 \mathrm{~h})(\mathrm{mL})$ * & $588 \pm 451$ & $561 \pm 519$ & $600 \pm 417$ & 0.55 \\
\hline Revision surgery for hemostasis (24h) • & $10(4 \%)$ & $4(5 \%)$ & $6(3 \%)$ & 0.50 \\
\hline Postoperative infection - & $22(8 \%)$ & $8(10 \%)$ & $14(8 \%)$ & 0.73 \\
\hline $\begin{array}{c}\text { Postoperative AKF } \\
\text { Highest creatinine level }(\mu \mathrm{mol} / \mathrm{L}) \text { * }\end{array}$ & $\begin{array}{l}27(10 \%) \\
97 \pm 76\end{array}$ & $\begin{array}{c}10(12 \%) \\
87 \pm 32\end{array}$ & $\begin{array}{r}17(9 \%) \\
101 \pm 89\end{array}$ & $\begin{array}{l}0.61 \\
0.06\end{array}$ \\
\hline IGS II * & $27 \pm 9$ & $27 \pm 9$ & & 0.95 \\
\hline Length of stay in ICU (days) * & $3.2 \pm 2$ & $3.5 \pm 1.9$ & $3.1 \pm 2.1$ & 0.18 \\
\hline Death before day 28 . & $7(3 \%)$ & $1(1 \%)$ & $6(3 \%)$ & 0.44 \\
\hline
\end{tabular}

* Mean +/- standard deviation • Number of patients (percentage)

AKF: acute kidney failure. ICU: intensive care unit. 